\title{
Farmakoterapie po infarktu myokardu
}

\author{
Dopis ke stejnojmennému úvodníku Jiřího Vítovce a Jindřicha Špinara \\ (Cor Vasa 2009;51(2):90-1)
}

Autoři otevřeli svůj úvodník citátem z mé knihy Kardiologie praktického lékaře $(1967,2$. vydání), kterým je uveden oddíl o terapii infarktu myokardu, kde jsou shrnuty zásady léčby. K tomu pak poznamenali: „Ale doporučení, jakou farmakoterapii uživat po prodělaném srdečním infarktu, zde nelze jednoznačně nalézt." - Konec citátu; následuje další odstavec, v němž píší, co uvádí Jiří Widimský po dvaceti letech.

Konstatování právě těchto autorů mne překvapilo a vyhledal jsem svůj původní text. Hned v dalším odstavci na str. 225 doporučuji s patřičným odůvodněním morfin a Dolsin, níže je-li třeba - skopolamin, popř́padě Librium, antihistaminika a Nozinan.

Na další straně 226 dole je odkaz na str. 222, kde je podrobně popsána léčba šoku s přesným uvedením postupu při aplikaci noradrenalinu (včetně technických detailů a ošetření komplikací) a jsou jmenovány i léky, jimiž možno noradrenalin nahradit, a to pod generickými i výrobními názvy. V posledním odstavci na str. 226 už jde o antikoagulaci; hned v prvním odstavci na str. 227 píši: „Léčbu začínáme heparinem, druhý den podáváme zároveň Pelentan, abychom dosáhli co nejrychleji a nejúčinněji snížení srážlivosti." Následuje popis kontroly srážlivosti, komplikací a jejich ošetření, s odkazem

\section{Odpověd' MUDr. Pavlu Jeriemu}

Milý Pavle,

myslíme si, že jde o pouze drobné nedorozumění. Naše články nejsou věnovány léčbě akutní fáze infarktu myokardu, ani léčbě komplikacím po IM. Vše samozřejmě, s ohledem na dobu publikace, ve svých obou vydáních Kardiologie praktického lékaře, uvedeno máš. My jsme články koncipovali jako léčbu ambulantní, dlouhodobou a budeš zřejmě s námi souhlasit, že ani morfin či dolsin, ani heparin, ani pelentan, určitě ne fibrilolytika či skopolamin do dlouhodobé léčby po infarktu myokardu nepatří. Tvá knížka nám byla vždy skvělou učebnicí praktic- na Protamin Spofa a Kanavit. V dalším odstavci jsou uvedeny interakce, s vyjmenováním všech látek zvyšujících protrombinovou aktivitu.

V posledním odstavci na stejné straně 227 je již odkaz na fibrinolytickou léčbu a nahoře na str. 228 už je zmíněna streptokinasa a urokinasa, které byly tehdy ve stadiu experimentálního a klinického zkoušení. Poté následuje doporučení léků, které mohou pomoci u těžkých hypotenzních stavů, a jež se nám osvědčily, jako např. hydrokortison; upozorňuje se i na látky, které mohou $\mathrm{v}$ akutním stadiu stav zhoršit - např. nitráty a puriny.

Ke konci kapitoly jsou shrnuty praktické pokyny, týkající se též stravy a sexuálního života: „Pokud se při styku dostavují anginózní bolesti, doporučíme předem nitroglycerin, př́ípadně v kombinaci s theofylinem a chinidinem."

Tak nevím, co autorům úvodníku, pokud jde o doporučení farmakoterapie, ještě „jednoznačně chybí. Navíc: je to vše uvedeno už v prvním vydání Kardiologie praktického lékaře z roku 1964 !

\section{Pavel Jerie}

ké kardiologie, a také proto jsme ji citovali. Pravděpodobně $\mathrm{v}$ době šedesátých let minulého století nemocný po nekomplikovaném infarktu doporučení $\mathrm{k}$ dlouhodobé farmakoterapii nedostal, pomineme-li doporučení nitroglycerinu. Většina farmakoterapie $\mathrm{v}$ tvé knížce je zaměřena především na léčbu akutního stavu a/nebo na léčbu komplikací, a jistě v té době šlo o vysoce moderní pojetí.

\section{Tvoji Jiří a Jindra}

